\title{
Andrzej Stasiuk, tekstowe figury doświadczenia
}

\author{
ZBIGNIEW KLOCH \\ Uniwersytet Warszawski \\ Instytut Badań Literackich PAN
}

\begin{abstract}
AвsTract. Kloch Zbigniew, Andrzej Stasiuk, tekstowe figury doświadczenia [Andrzej Stasiuk: text-based figures of experience]. "Images" vol. XXVII, no. 36. Poznań 2020. Adam Mickiewicz University Press. Pp. 281-288. ISSN 1731-450X. DOI 10.14746/i.2020.36.17.

The aim of the article is to show the role of various metaphorical practices that are a dominant structural feature of Andrzej Stasiuk's prose, used to construct his textual reality. Comparisons, metaphorical statements, and enumerations represent textual figures that transform the described experience of the world from the perspective of the speaking subject, subjectivising and constructing reality, rather than merely representing it. In both his novels and feuilletons, Stasiuk relates his experiences of the world in different temporal orders, constructing them on a textual level. Yet his thoroughly subjective prose preserves the conventions of realism. At the same time, Stasiuk quite often refers to the genre of the road novel, both in his fiction and in his journalism. Textual figures of experience are his basic means of describing the presented world.
\end{abstract}

KEYWORDS: figure, experience, road novels, metaphor, enumeration, symbolization

Andrzej Stasiuk pisze o tym, co widzi, i o tym, czego doświadcza. O doznawaniu różnych aspektów rzeczywistości: „Od dawna wydaje mi się, że jedyną wartą opisu rzeczą jest światło, jego odmiany i jego wieczność”[1]. Opisać światło to oznaczyć pewien indywidualny punkt widzenia rzeczywistości, to patrzeć z perspektywy indywidualnego doświadczenia, przeżycia, z perspektywy personalnej percepcji świata. To zarejestrować go w rozumieniu fotograficznym, bowiem fotografia wiąże się z ekspozycją, którą wyznaczają warunki oświetleniowe. Ale fotografia jest zarazem reprodukcją i konstrukcją.

Piszę „Stasiuk”, bo w większości przypadków prozy tego autora narrator skonstruowany jest w taki sposób, że można go łatwo utożsamiać $\mathrm{z}$ autorem, co ułatwia kontekst wywiadów ze Stasiukiem, jego felietonów w „Tygodniku Powszechnym" oraz konstrukcja doświadczenia opisywanego w powieściach. Stasiuk podróżuje i doświadcza. Tak jest chociażby w Jadąc do Babadag, Wschodzie, w Grochowie. Opowiada $\mathrm{w}$ różnych perspektywach czasowych, świat wypowiedziany staje się w ten sposób światem zrozumianym, zawsze z perspektywy czyjejś świadomości. Komentatorzy prozy Stasiuka ten typ opowiadania nazywają "narracją poszukującą”, "narracją wędrowca”[2].

Piszący o Stasiuku wskazywali na podobieństwa jego twórczości z literaturą polską z lat wcześniejszych, z twórczością Marka Hłaski i Marka Nowakowskiego, na podobieństwa konstrukcji męskich postaci[3], a także podobieństwa do prozy amerykańskiej różnych okresów. Tu chciałbym zwrócić uwagę na fakt chyba nieodnotowany; związki Stasiuka z prozą

[1] A. Stasiuk, Dukla, Wołowiec 1999, s. 17. Na sprawę „widzenia” rzeczywistości w prozie Stasiuka zwracała uwagę krytyka. Zob. między innymi: Dukielskie światło według Stasiuka. <https:// magdalenamisztelas.blogspot.com/2014/02/ dukielskie-swiatlo-wedlug-stasiuka.html>, dostęp 1.07.2019.

[2] A. Frankowiak, „Wszystko zaczyna się od mojej obecności". Sekretny przekaz prozy Stasiuka, „Napis” 2011, XVII, s. 71.

[3] K. Solan, Proza Andrzeja Stasiuka jako „podręcznik męskości" - rzecz o tożsamości męskiej, „Barbarzyńca” 2009, 2(15). 
amerykańską widziałbym raczej w kategoriach pewnych podobieństw gatunkowych. Opowiadania o tym, co się widzi, gdy się człowiek przemieszcza, wędruje, odsyłają do popularnych gatunków kultury masowej, do powieści drogi czy filmu drogi. Teksty drogi opowiadają o przemieszczaniu się w przestrzeni; ruch w czasie stanowi tu elementarny wyznacznik tematyczny gatunku. To także sposób doświadczania świata. Ruch napędza fabułę niejako w sposób konieczny. Gdy idę, jadę, prawdopodobne jest, że kogoś spotkam, a z pewnością wydarzy się coś, co przyciągnie moją uwagę. Film drogi unaocznia tę banalną prawdę, a niezliczone powieści drogi (chronologicznie wcześniejsze niż filmy i dziś popularne) ją potwierdzają. Podróżowanie jest sposobem bycia i odmianą bytu. „Podróżować to znaczy żyć. A w każdym razie żyć podwójnie, potrójnie, wielokrotnie" [4]. Fabuła Dukli oparta jest na figurze ciągłych powrotów do tego miasta i podróżach w głąb własnej pamięci. Nawet felietony Stasiuka, drukowane w „Tygodniku Powszechnym", budowane są bardzo często z uwzględnieniem sytuacji „wyjścia” i „przemieszczania się" w bliższej lub dalszej okolicy od miejsca zamieszkania. Tekstowe „idę” lub "jadę" może być w tym przypadku łatwo utożsamione $\mathrm{z}$,ja” autorskim, czemu sprzyja semio-

[4] A. Stasiuk, Fado, Wołowiec 2006, s. 39.

[5] Z perspektywy tekstowej, czy też czysto językowej, status ,ja” wpisanego w wypowiedź jest taki sam w zdaniach: „Biorę piłę łańcuchową, pickupa i ruszam na ten niewesoły obrzęd. Co roku wyprawiam wczesny pogrzeb kilku drzewom. Zenek powiedział, żeby zostawić parę dla dzięciołów” (A. Stasiuk, Ścinanie, „Tygodnik Powszechny” 2019, nr 3665, s. 57) i „Nie doczekałem się i musiałem iść. Widziałem ich jeszcze przez szybę [...]. Nie byli stąd, ale jechali w podobne miejsce. Powiedzmy gdzieś do Żłobisk albo jeszcze dalej pod samą granicę" (A. Stasiuk, Taksim, Wołowiec 2009, s. 9). O statusie fikcyjności bądź prawdziwości „ja” wypowiadającego decyduje tu wpisanie tekstu w szerszy kontekst gatunkowy (felieton, powieść).

[6] Stownik poprawnej polszczyzny PWN, pod red. A. Markowskiego, Warszawa 1999, s. 166.

[7] Zob. R. Nycz, Literatura jako trop rzeczywisto- tyczne oznaczenie cyklu („felieton”). Warto dodać, że lektura biograficzna jest także konwencją powieści drogi, silnie zakorzenioną $\mathrm{w}$ tradycji. Jak w przypadku Jacka Kerouaca ( $W$ drodze), którego bohater, Sal Paradise, uważany był za alter ego autora. Ten styl interpretacji jest jednak rzadszy w przypadku tekstów należących do kategorii fiction niż reality (odwołuję się do rozróżnień typowych dla amerykańskiej teorii literatury) [5]. Bardzo wiele spośród utworów Stasiuka bardziej lub mniej wyraźnie nawiązuje do tekstów drogi. A „droga”, „podróżowanie” zakładają przecież gromadzenie doświadczeń.

Doświadczenie jest tym, co przeżyte i uwewnętrznione. Ale nie każdemu przeżyciu można przypisać status doświadczenia, którego właściwością jest trwanie w czasie. Nasz kontakt ze światem układa się w sumę lub konstelację doświadczanego, niekiedy staje się traumą, którą język odnotowuje w zwrotach w rodzaju: „doświadczenie życiowe”, „doświadczenie choroby”, „doświadczenia miłosne”, „doświadczenia wojenne". Doświadczenie gromadzone jest na podstawie obserwacji życiowych i przeżyć, jest zatem pochodną naszego kontaktu $\mathrm{z}$ rzeczywistością. Śladów, jakie ten kontakt pozostawia w naszej pamięci, świadomości, psychice. Takie właśnie komponenty semantyczne znaczenia wyrazu znajdujemy w słownikowych definicjach określenia „doświadczać”[6]. Można zaryzykować banalne, lecz prawdziwe z pewnością stwierdzenie, że literatura powstaje $\mathrm{z}$ tak czy inaczej rozumianego doświadczenia (z zapisu przeżycia świata albo z potrzeby uzewnętrznienia doznań psychicznych). Można więc o literaturze mówić (tu i dalej podążam za myślą Ryszarda Nycza) jako o „tropie rzeczywistości”, która objawia się w tekście, bądź jako językowa kopia świata (poetyka mimesis), bądź jako jej tekstowa konstrukcja semiotyczna, nie będąca prostym odwzorowaniem tego, o czym się mówi (poetyka epifanii). Jest więc literatura i odwzorowaniem i poznawaniem[7]. Analizując zakres znaczeniowy kategorii doświadczenia, jaki utrwalony został w polszczyźnie XV i XVI wieku (na podstawie słowników Karłowicza, Lindego, Słownika Warszawskiego, Trzaski, Ewerta 
i Michalskiego) Nycz stwierdza, że „doświadczać (się)” to tyle, co „poddać się próbie”, „doznawać” (ale także - „poznawać”), „dowodzić”, „udowodnić”, „okazać”, „oświadczyć”, „dawać świadectwo". Nycz za prymarne znaczenie tego wyrazu uznaje semantykę „doświadczenia jako 'poddawania próbie', w sensie, najogólniej mówiąc: narażenia na ryzyko [...] wystawienia na kontakt ze światem [...]"[8]. Doświadczenie nie może więc istnieć poza relacją z rzeczywistością (jakimś światem) i łączy się z nieprzewidywalnością efektów tego kontaktu. W innym miejscu stwierdza przywoływany badacz:

\footnotetext{
Jeślibyśmy mieli kierować się tą nitką etymologicznych znaczeń, to można by powiedzieć, że doświadczenie jest efektem 'poddawania się próbie', narażającego na ryzyko nieprzewidywalnego kontaktu podmiotu ze światem, zachodzącego poprzez zmysłowe uczestnictwo ('doznanie') z pozycji widza, który zdobywa w ten sposób wiedzę, [...] 'oświadcza' - objawia, publicznie okazuje, także językowo utrwala oraz przekazuje - i zarazem sobą (własną tożsamością świadka) poświadcza (gwarantuje) jej prawdziwość[9].
}

\section{Prawda doświadczenia jest prawdą przeżytą}

Literatura musi niejako $\mathrm{z}$ konieczności znaleźć semantyczne i stylistyczne figury, które pozwolą wyrazić doświadczenie piszącego. Doświadczenie, które nie znajduje językowego wyrażenia, nie może zaistnieć społecznie. Podobnie jak myśl, a szerzej - wszelka refleksja nad światem, która zanim zostanie zakomunikowana, istnieje jedynie potencjalnie, choć przecież istnieje[10]. Zapisanie doświadczenia w literaturze musi być oznaczone tekstowo, zaś sposób, w jaki zostało oznaczone, nadaje wypowiedzi właściwości indywidualne. $\mathrm{W}$ ten sposób powstają tekstowe figury, które łączą myśl z wypowiedzeniem. Wiele lat temu napisał Gerard Genette:

Istnieje myśl - tzn. sens, taki sam u dobrych i złych poetów, który można wyrazić w jednym suchym i płaskim zdaniu; istnieje też sposób „oddania sensu” [...] i w tym cała różnica. Widzimy, że tutaj między literą a znaczeniem, między tym, co poeta napisał, a tym, co myślał, rodzi się rozpiętość, przestrzeń ta także podporządkowuje formę. Formę te nazywa się figurą [11].
Możemy zaryzykować stwierdzenie, że Stasiuk - $\mathrm{z}$ różnym nasileniem - pisze o doświadczeniu, które w zasadzie może spotkać każdego, choć trudno byłoby nazwać je doświadczeniem powszechnym. Zima to cykl opowieści o ludziach żyjących w polskim ,interiorze” (Beskid Niski), gdzie $\mathrm{w}$ istocie niewiele się dzieje, $\mathrm{w}$ innym miejscu pisarz dzieli się z czytelnikiem doświadczeniami z podróży do Rumunii, na dalszy i bliższy Wschód (Nie ma ekspresów przy zóltych drogach, Wschód, Jadąc do Bagadag). $\mathrm{W}$ pewnym sensie są to światy podobne, $\mathrm{w}$ jakimś - różne; doświadczanie miejsc nowych wywołuje myśl o doświadczeniach i zdarzeniach wcześniejszych, tych z dzieciństwa, z wczesnej młodości. „Reality” miesza się tu z „fiction” (Taksim). Są to jednak (przynajmniej teoretycznie) światy każdemu dostępne, bowiem prawie każdy może trafić do więzienia (Mury Hebronu) lub wyruszyć w podróż na Wschód. Szczególną rolę w opisie takiego, w sumie banalnego świata, odgrywać zatem musi sposób jego przedstawiania. Powiada Stasiuk w wielokrotnie cytowanej przez komentatorów jego twórczości odpowiedzi na ankietę z „Tekstów Drugich”:

Jeśli coś jest dobrze napisane, to ma wartość niezależnie od przedmiotu, którym się zajmuje. Od 'co' bardziej interesuje mnie 'jak' [...]. Te wszystkie sprawy jak sens, prawda czy właśnie wartości są produktami ubocznymi języka[12].

Genette wyprowadza pojęcie figury z retorycznych traktatów, głównie francuskich. Bez wchodzenia w taksonomię retoryczną (figury słów, figury myśli, klasyfikacje szczegółowe, dobrze znane badaczom), o figurach w prozie

ści. Kraków 2001.

[8] Idem, Poetyka doświadczenia. Teoria-nowoczesność-literatura, Warszawa 2012, s. 233-234.

[9] Ibidem, s 235.

[10] Zob. H. Arendt, Filozofia i metafora, przekł.

H. Buczyńska-Garewicz, „Teksty” 1979, 5(47). Powiada Arendt: „Myśli na to, aby się zdarzyć, nie wymagają komunikacji, nie mogą się jednak zdarzyć bez wypowiedzenia ich - milczącego lub brzmiącego - w dialogu", s. 168.

[11] G. Genette, Figury, przekł. W. Krzemień, „Pamiętnik Literacki” 1997, nr 68, z. 2, s. 296-297. [12] A. Stasiuk, Świadectwa, „Teksty Drugie” 
Stasiuka chcę tu mówić jako o pewnych procedurach tekstowych, które nadają określony kształt opisywanej rzeczywistości. Jak każdy pisarz, Stasiuk zdradza pewne upodobania do określonego rodzaju figur, które, pomimo zmian poetyki jego utworów, mają znaczącą frekwencję. Pierwsza z nich to szeroko rozumiana metafora. Ale Stasiuk chętnie używa też innych figur tekstowych, które metaforyzują rzeczywistość.

Metafora (i jej pochodne) jako sposób tekstowego wyrażania doświadczenia pojawia się w prozie Stasiuka dość często, w tekstach $\mathrm{z}$ różnych okresów twórczości. Rzadko kiedy w postaci klasycznej figury słów (odwołuję się tu do podziału figur retorycznych na figury słów i figury myśli), częściej jako wypowiedzenie metaforyczne, oparte na porównaniu, które zapoczątkowuje fragment następującej dalej narracji. Wypowiedzenie metaforyczne subiektywizuje opisywaną rzeczywistość. Jej postać czy obraz wyłania się z metafory. I jest to zazwyczaj obraz świata widziany z czyjejś perspektywy. W takiej czy innej postaci metafora jest przecież językowym narzędziem „analizy rzeczywistości”[13]. Nazywanie łączy się z poznawaniem, a u Stasiuka - często z symbolizacją opisywanego świata. Nie chodzi tu o proste zastąpienie jednego słowa innym, trop wąsko rozumiany, lecz figury tekstowe, które zmieniają kształt opisywanej rzeczywistości.

Od ściany do ściany. Od ściany do ściany. Od okna do drzwi. Do drzwi od okna. Odscianydościanydooknaoddrzwi. Mam miejsce na ruch i członki posłuszne rozkazom myśli. Mam czas[14].

1996, nr 5 (41), s. 119.

[13] T. Dobrzyńska, Od słowa do stowa. Studia o metaforze, Warszawa 2012. Cytowane określenie pochodzi ze strony 116. Trochę dalej Dobrzyńska pisze: „Użycie metafory przetwarza obraz rzeczywistości, nadając jej kształt zależny od aktywności myślowej i przeżyć mówiącego" (s. 117). Prace o metaforze tworzą tak wielką bibliografię, że nie będę próbować jej tu przywoływać. Poprzestanę na odwołaniu się do prac Dobrzyńskiej, od których moje myślenie na tren temat jest $\mathrm{z}$ pewnością zależne; zob. eadem, Metafora. Wrocław 1984, eadem, Mówiąc przenośnie..., Warszawa 1994.

[14] A. Stasiuk, Mury Hebronu, Warszawa 1992, s. 7.
Z czysto językowego punktu widzenia nie ma w tym fragmencie żadnych wyrazistych metafor, choć tekst (poprzez powtarzanie fraz) metaforyzuje zjawisko ruchu w ograniczonej przestrzeni. Powtarzanie zdań, krótkich zdań oznajmujących, silnie zrytmizowanych, z użyciem zapisu pozbawionego spacji, przekształca wypowiedź w metaforę ruchu w więziennej celi, którego postać wyznacza sytuacja zamknięcia, przestrzennego ograniczenia. Powtarzanie opisu czynności chodzenia po celi symbolizuje $\mathrm{z}$ kolei sytuację uwięzienia, zamknięcia. To punkt widzenia, który dominuje w Murach Hebronu, gdzie świat spostrzegany i opowiadany jest z perspektywy więźnia.

W najkrótszym opowiadaniu tomu, Centuria, narrator patrzy przez okno celi na ćwiczenia strażników więziennego nadzoru ( $(, .$. dziewiątka!... dziewiątka!... podejdź do okna... widzisz ich...?"). Widziany tej perspektywy oddział przekształca się w rzymską centurię. Zdarzenie nazwane w określony sposób nadaje rzeczywistości właściwości świata $z$ innej epoki, cechy innego porządku. Punktem wyjścia jest tu dostrzeżenie podobieństw pomiędzy wyglądem tarcz używanych przez oddział a twarzą (motywacja metafory), punktem dojścia - widzenie przekształcające oddział strażników w oddział taktyczny legionów rzymskich.

Szereg szarych tarcz łypie niewielkimi źrenicami z pleksiglasu. Martwe, wszystko widzące oczy gada. Czarne, długie pałki zwisają w prawych dłoniach dotykając niemal betonowych płyt dziedzińca. [...] Krzyk kurduplowatego kapitana podrywa ich do marszu, do drobnego truchtu. Ciężkie buciory grzmocą o beton, razem z kurzem podnosi się echo. Szyki mieszają się, kreślą jakieś zawiłe wzory w przestrzeni dziedzińca. Gdyby chcieli, mogliby uformować słynnego rzymskiego „żółwia”, pełzającego wśród murów upadających miast. Szara centuria, szara i pozbawiona dźwięku metalu, ale odporna na broń, z jaką może się zetknąć[15].

Praktyki figuracyjne konstruują narracje zgodnie z typowym i wielokrotnie opisywanym schematem funkcjonowania wypowiedzi metaforycznej: myślę o jednej rzeczy w kategoriach innej rzeczy, co pozwala mi mówić o świecie w określony sposób. Lektura świata jest jego odczytywa- 
niem zmetaforyzowanym i ten punkt widzenia narzucany jest czytelnikowi[16]. Z rzeczywistości zastanej wyłania się w ten sposób rzeczywistość odczuwana, spostrzegana subiektywnie.

Lipiec wisiał nad wsią jak niebieska blacha. Rzeka cuchnęła mułem. Polowałem na jej [tj. dziewczyny Z.K.] obecność jak półślepy kot[17].

Narracja Stasiuka w wielu miejscach jego tekstów budowana jest przy użyciu zdań o charakterze metaforycznym, przeplatanych wypowiedzeniami, które metafor nie zawierają. Jest tak między innymi w Dukli:

Miałem trzynaście lat i dostałem pierdolca. Słońce nie zachodziło tego lata. Stało bez przerwy w zenicie i mizerne cienie stawiały rzeczywistość pod znakiem zapytania[18].

Pierwsze zdanie cytowanego fragmentu jest prostym stwierdzeniem, oznajmieniem w kwestii czasu i sytuacji podmiotu, a zarazem oznaczeniem stanu emocjonalnego tego, który opowiada. Narrator Dukli wypowiada to zdanie we fragmencie retrospekcji, gdy jako podrostek podczas wakacji na wsi zakochał się bez pamięci w dużo starszej od siebie dziewczynie („A potem z mroku wyłoniła się ta dziewczyna i wmieszała między tańczących”, s. 26). „Pierdolec” to słowo z rejestru potocznej polszczyzny, typowe dla slangu młodzieżowego sprzed lat. „Pierdolec” oznacza silne, niekontrolowane emocje, trudne do opanowania. „Pierdolca” można „mieć” lub go „dostać” na punkcie kogoś lub czegoś. To typ emocji, które pojawiają się nagle, niespodziewanie, zaskakująco, jak w zdaniach: „Dostał pierdolca na punkcie zdrowej żywności” albo „Jego stosunek do pracy to po prostu - pierdolec!". Elementy znaczeniowe słowa dają się interpretować w ten sposób, że określa ono w potocznym języku znamiona obsesji. Nie jest to z pewnością wyraz $z$ repertuaru wyszukanej polszczyzny. Myślę, że jego metaforyczność była silniej niż dziś odczuwana w latach siedemdziesiątych, do których odnosi się narracja Stasiuka. Dziś to raczej słowo zleksykalizowane, powszechnie zrozumiałe, choć, o ile wiem, niezbyt często używane w dzisiejszym slangu młodzieżowym, który niejako z natury swej dość szybko ewoluuje. Metaforycz- ność przytoczonego zdania jest więc niewielka, prawie żadna. Jeżeli jest odczuwana, to za sprawą najbliższego wypowiedzeniowego kontekstu. Trudny bowiem do pomyślenia jest świat, gdzie słońce przestaje zachodzić, zatem taki typ powiadamiania o rzeczywistości apeluje o lekturę metaforyczną. Sens analizowanego akapitu Dukli można więc sparafrazować następująco: „myślę o doświadczeniu z przeszłości, niepowtarzalnym, wyjątkowym, którego znaczenie można opisać za pomocą wypowiedzi metaforycznej, zrównującej jego wartość z zaburzeniem odwiecznego porządku świata”. Banalne i w sumie powszechne doświadczenie (zauroczenie miłosne) przedstawione jest tu za pomocą figury, która przekształca je w zdarzenie wyjątkowe, czego dokonuje się za pomocą metaforyzacji, bazującej na potocznej wiedzy o świecie (niemożliwe jest, aby słońce przestało zachodzić). Warto może powtórzyć: powszechnie doświadczane zdarzenie wyłania się ze słów, których figuratywność kreuje to doświadczenie jako wyjątkowe. Realność zyskuje $\mathrm{w}$ ten sposób znaczenie magiczne[19].

Magiczność świata to pochodna widzenia, spostrzegania go w określony sposób. Spostrzeżenia są przecież czymś subiektywnym, nawet jeśli dotyczą obiektywnej rzeczywistości. Świat opisany w określony sposób zostaje zmetaforyzowany, a więc odczuwany subiektywnie. W dawnym tekście o metaforze Paul Ricoeur twierdzi, że ważnym elementem poznawczego

[15] Ibidem, s. 27.

[16] W tym miejscu można odwołać się do koncepcji ramy modalnej budującej wypowiedź metaforyczną z prac Dobrzyńskiej lub znanej koncepcji Lakoffa-Johnsona: zob. T. Dobrzyńska, Mówiąc przenośnie..., s. 11-28; G. Lakoff, M. Johnson, Metafory w naszym życiu, przekł. i wstep T.P. Krzeszowski, Warszawa 1988.

[17] A. Stasiuk, Dukla..., s. 28.

[18] Ibidem.

[19] Na tę właściwość prozy Stasiuka zwrócono już wcześniej uwagę: „Dukla pełni zatem funkcję magicznego lustra, w którym chce on [Stasiuk] odpoznawać siebie. Odjazdy i przyjazdy, zapisywane jak kartki z podróży i pobytów układają się w metaforę życia." B. Małek, Czy realizm magiczny? O prozie Andrzeja Stasiuka, „Annales Universitatis Paedagogicae Cracoviensis. Studia 
aspektu procesu metaforycznego jest tak zwane „widzenie jako”. Widzenie, które ukierunkowuje myślenie, to zaś przybiera kształt określonego rodzaju figury tekstowej, łączącej różne porządki[20]. A przy tym opisywany świat może stać się czymś niepewnym, dwuznacznym, powstałym z nakładania się na siebie kilku różnych rzeczywistości, na przykład widzianej i pamiętanej, albo pejzażu i jego podobieństwa do dzieła sztuki,

Wszystko, na co pada blask, zmierza ku własnej idei, ku światu, który chroniony jest przez ograniczoność naszych zmysłów. [...] Tak. Ale to wszystko jest ledwie podejrzeniem. Natomiast, gdy oglądałem potem reprodukcję Krajobrazu z tańczacymi, którego oryginał wisi w jakiejś rzymskiej galerii, dostrzegłem, że góra Sorakte, zamykająca kompozycję, jest identyczna jak kształt Cergowej. Zwłaszcza gdy jedzie się od strony Żmigrodu[21].

Figuratywność wypowiedzi otwiera przestrzeń interpretacyjną. U Stasiuka podobieństwo obrazu, sytuacji, zdarzeń i osób prowadzi do refleksji na temat tożsamości świata i bytu, a przynajmniej ich przestrzennie oznaczonych obrazów. W szędzie tam, gdzie się było, gdzie się dojechało i co później zostało opisane, można zobaczyć młodych facetów, którzy palą i piją piwo (rakiję, palinkę), rozmawiają. Tyle że w różnych językach. I to z pewnością symbolizuje podobieństwo dzisiejszego świata, przynajmniej w pewnym zakresie i pod określonymi szerokościami geograficznymi. W prozie Stasiuka rzeczywistość doświadczana jest przy tym różnymi zmysłami, czego tekstowym odpowiednikiem jest figura synestezji (co odnotowano[22]).

HistoricoLiteraria 1" 2002, s. 165.

[20] P. Ricoeur, Proces metaforyczny jako poznanie, wyobrażenie i odczuwanie, przekł.

G. Cendrowska, „Pamiętnik Literacki” 1984, z. 2, s. 269-286.

[21] A. Stasiuk, Dukla..., s. 20.

[22] B. Witosz, Obrona bliskości w prozie Stasiuka. Pisze autorka: „W opracowaniach poświęconych figurom i tropom stylistycznym zwraca się również uwagę, że metafory synestezyjne, łącząc zjawiska ze sfery różnych doznań, wyrażają integralność przeżyć, które potocznie traktowane są jako rozdzielne”. „Teksty Drugie” 2002, nr 5, s. 138. [23] A. Stasiuk, Dukla..., s. 86

[24] Idem, Grochów, Wołowiec 2012, s. 8.
Figurą, która nadaje metaforyczny wymiar opisowi, bywa też u Stasiuka powtórzenie. Powtarza on wątki, motywy (powroty do zdarzeń z przeszłości, młodości, dzieciństwa). Powtarza zdania w podobny sposób zrytmizowane („No więc wracam do Dukli [...]”, „No więc tylko zdarzenia”, „No i nie myliłem się”, „Miałem trzynaście lat i niewiele rozumiałem" - Dukla, s. $13,24,39,36$ ), ale przekształcone w takim stopniu, aby nie stanowiły prostego powtórzenia. Powtarza całe fragmenty wypowiedzi $\mathrm{w}$ wersji zmodernizowanej.

Przypomina mi się moja babka, która wierzyła
w duchy. Często je widywała. Dom stał w starym
sadzie na końcu wsi. Opowiadała o swoich widze-
niach zupełnie spokojnie i naturalnie. Zjawiały się
w dzień albo w nocy. Wchodziły do kuchni, zwy-
czajnie otwierając sobie drzwi[23].

No więc babka wierzyła w duchy. I to nie żadną tam strachliwą albo wyrozumowaną wiarą, jaką zyskuje się dzięki okazjonalnym kontaktom z zaświatami, dzięki snom albo przywidzeniom - nie nic $\mathrm{z}$ tych rzeczy[24].

Powtórzenie w tekście Stasiuka wskazuje na szczególnie ważne fragmenty narracji. Babka jest naturalnym łącznikiem między porządkiem tego i tamtego świata, doświadcza tajemnic, które nie są dla wszystkich widoczne. Przyjazdy i wyjazdy z Dukli układają się w rytm powrotu do wcześniejszych doświadczeń, składających się na tożsamość opowiadającego. Opowiadane w ten sposób doświadczenie życiowe składa się z wrażeń, zdarzeń i przedmiotów (kolorów, dźwięków), przedstawianych za pomocą wyliczeń, a więc z użyciem jednej z wielu możliwych wersji figury enumeracji.

W zielonkawych wodach Dukielki nic się nie odbijało. Z prawej piętrzyły się ogródki, komórki i tylne ściany kamieniczek, które od Rynku są gładkie, pastelowe i przywołują na myśl konkurs cukierników. Róż, zielonkawa pistacja, spłowiały piernikowy brąz i kremowy budyń ułożone w wykusze, fryzy, gzymsy i odęte, osiadłe balkony[25].

W osiemdziesiątym trzecim w rusińską Wielkanoc zobaczyłem je po raz pierwszy, po raz pierwszy stanąłem w kolejce i potem stawałem już do końca, cały czas w tym znajomym zapachu. Co to było? Słodycze, 
cynamon, marmolada, cukier waniliowy, wędzonka, wietrzejące butelki po piwie, papierosowy dym, ciała ludzi stojących w kolejce? Wszystko razem[26].

Konstruowane w ten lub w podobny sposób serie wyliczeń oznaczają świat na zasadach synekdochy - część, element pejzażu, przestrzeni odsyła do rzeczywistości, która stanowi całość określonego rodzaju.

Figuratywność tekstu przekształca opis rzeczywistości w idiom doświadczenia. Figura jest tekstowym sposobem jego literackiego kodowania. Doświadczenie wyłania się z zapisu. Synekdochiczność wskazuje na wielość możliwych doświadczeń, z których każde mówi coś o podmiocie wypowiadającym. A ten ewoluuje, zmienia się w czasie, choć zachowuje tożsamość. Tak dzieje się przynajmniej w Dukli, choć podobną praktykę znaleźć można w innych utworach Stasiuka. Każde z wypowiedzeń nieco inaczej sytuuje podmiot w stosunku do przeszłości, dlatego powtórzenie rzadko kiedy jest powtórzeniem dokładnym, najczęściej jest powtórzeniem częściowym - fragmentu, zdania, sytuacji, $\mathrm{z}$ dopowiedzeniem albo $\mathrm{z}$ wyraźną transformacja motywu (babka, która rozmawiała $\mathrm{z}$ duchami). Pozwala nieco inaczej zobaczyć zdarzenia z przeszłości, coś więcej zrozumieć. Jak w Dukli:

Miałem trzynaście lat i dostałem pierdolca. (s. 28)

Miałem trzynaście lat i niewiele rozumiałem. Czułem tylko, że w jednej chwili moja miłość przestała być niewinną i wstydliwą grą i stała się czymś zakazanym. Miałem trzynaście lat i czułem, że piękno zawsze zawiera $\mathrm{w}$ sobie groźbę, że $\mathrm{w}$ istocie jest odmianą zła, odmianą, której możemy pragnąć tak, jakbyśmy pragnęli dobra. (s. 36)

No więc Dukla. (s. 44)

No więc gdy powracam do Dukli nie obchodzą mnie dyliżanse ani Żydzi, ani reszta. (s. 45)

W cytowanych frazach widzieć można nakładające się punkty widzenia podmiotu zakotwiczonego w różnorakich porządkach czasowych: trzynastolatka, bez pamięci zakochanego, i tego, który w innym czasie, choć w tym samym miejscu mówi (myśli) o tamtym doświadczeniu. Doświadczenie u Stasiuka ma zatem charakter palimpsestalny, jedna z jego warstw osadzonych w czasie przenika przez drugą, wyłania się stopniowo spoza słów. Dzięki użyciu takiej bądź innej figury, która jest zamiennikiem rzeczywistości, tej doświadczanej i tej wewnętrznej. Przeskoki, przesunięcia, uskoki czasowe zmiany perspektyw nie zawsze są wprost oznaczone. Niekiedy sprawiają kłopoty interpretacyjne. Zawsze jednak budują tożsamość miejsca i doświadczenia. Niekiedy motywują zaskakująca zmianę języka albo stylistycznego rejestru. Ratusz na rynku w Dukli spostrzegany w odległej perspektywie czasowej zmienia się w nieistniejący wyobrażony dwór, opowiadany z innej stylistycznej perspektywy, archaiczną polszczyzną, z jej pisownią i składnią.

Popołudnie powoli rozmyło kontury ratusza i w jego miejsce zjawił się dwór w Rynku oparkaniony drzewem, parkan pobity gontami, mieyscami poprawy potrzebuje. W tym dworze Izba stołowa, do tey Izby drzwi na zawiasach żelaznych, z klamką i haczykiem żelaznemi. [...] No więc tak było za tym nie istniejącym wtedy oknem trzysta lat temu[27].

Świat widziany z różnych perspektyw czasowych stanowi jednak pewne kontinuum, którego tożsamość zależna jest od percepcji podmiotu, wyłania się ze słów i nakładających się, przenikających się sposobów myślenia o rzeczywistości. Powtórzenie aktualizuje pracę pamięci $\mathrm{w}$ relacji do czasu przeszłego, w stosunku do tego, co już raz było widziane, przeżyte. Opowiadanie nadaje pamięci określony kształt językowy, język zaś modeluje kształt tego, co przeżyte, nadaje pamiętaniu wartość semantyczną. Wyliczenia pokrywają rzeczywistość kolekcjami przedmiotów, które pozostały $\mathrm{w}$ pamięci indywidualnej. To od niej można dopiero przejść do pamięci zbiorowej. Pamięć wprowadza przeszłość w teraźniejszość, zapamiętane pozostaje w świadomości, a więc może trwać w czasie.

Nie są to z pewnością wszelkie figury tekstowe, jakie byłaby w stanie wyznaczyć retorycznie zorientowana lektura prozy Stasiuka, lecz co najwyżej te, które wskazują na swoistości

[25] Idem, Dukla..., s. 14.

[26] Idem, Wschód, Wołowiec 2014, s. 7. 
poetyki. Porównanie metaforyczne, czy też symbolizacja opisywanego świata, pojawiają się w bardzo różnych wypowiedziach prozatorskich, chociażby u Olgi Tokarczuk. Ale metafora w wypowiedzi tego rodzaju służy często wyjaśnieniu zjawiska, które samo w sobie nie jest zrozumiałe tak po prostu, ponieważ jest wyjątkowe. Metafora pełni tu zatem przede wszystkim funkcje poznawcze. Raczej objaśnia świat niż go konstruuje.

Trudno to opisać, choć idzie o pojedyncze wydarzenie, w którym przecież wszystko dzieje się po kolei i na każdy ruch, na każdy obraz istnieje odpowiednie słowo... Może lepiej, jeśli opowie to świadek, szczególnie, że i tak wszystko opisuje. [...] Bo oto stało się, że schodził między nas duch. Zasłony między tym i tamtym światem zostały naruszone, ten czas tracił dziewictwo, przepychał się do nas duch, niczym $\operatorname{taran}[28]$.

Pierwszy akapit przytoczonego fragmentu jest wypowiedzią narratora, drugi - świadka zdarzenia (wstapienie ducha w Jakuba). Duch jest zjawiskiem nadprzyrodzonym, o ogromnej mocy, skoro jest tak silny jak taran i może przenikać porządki światów. A to wymaga użycia języka, który potrafiłby oddać wyjątkowość zjawiska. W taki przypadku język musi poradzić sobie $\mathrm{z}$ niecodziennością zdarzenia (u Tokarczuk metafora nie rozwija się jednak w bardziej rozbudowana narrację). U Stasiuka dominują raczej praktyki odwrotne: opowiadana rzeczywistość nie ma cech wyjątkowości. Istnieje wiele miasteczek jakoś podobnych do Dukli, wiele podobnych do siebie przestrzeni Wschodu, którym dopiero figura tekstowa nadaje wyjątkowość. To nie rzeczywistość, lecz jej doświadczanie jest czymś niepowtarzalnym, wyjątkowym. Figura nie tyle odtwarza, co kreuje ten świat. Przestrzeń pomiędzy myślanym a zapisanym musi zostać wypowiedziana za pomocą konstrukcji języka, które udatnie przekształcą doświadczenie w jego artystyczny zapis.

Figuratywność dzisiejszej polskiej prozy współczesnej z pewnością warta jest szczegó-

[27] Idem, Dukla..., s 44, 45

[28] O. Tokarczuk, Ksiegi Jakubowe, Kraków 2014, s. 684 . łowego opracowania. Tu można jedynie pokusić się o stwierdzenie, że dawne retoryki skupiały się na budowaniu klasyfikacji figur, podczas gdy dzisiejsze literaturoznawstwo częściej zajmuje się oznaczaniem ich funkcji poznawczej.

\section{B I B L I O G R A F I A}

Teksty Andrzeja Stasiuka

Mury Hebronu, Warszawa 1992

Świadectwa, „Teksty Drugie” 1996, nr 5 (41)

Dukla, Wołowiec 1999

Fado, Wołowiec 2006

Taksim, Wołowiec 2009

Grochów, Wołowiec 2012

Wschód, Wołowiec 2014

Arendt H., Filozofia i metafora, przekład H. Buczyńska-Garewicz „Teksty” 1979, 5(47)

Dobrzyńska, T., Metafora, Wrocław 1984

Dobrzyńska T., Mówiąc przenośnie..., Warszawa 1994

Dobrzyńska T., Od stowa do stowa. Studia o metaforze, Warszawa 2012

Frankowiak A., „Wszystko zaczyna się od mojej obecności”. Sekretny przekaz prozy Stasiuka, „Napis” 2011, XVII

Genette G, Figury, przekład W. Krzemień, „Pamiętnik Literacki” 1997, nr 68, z. 2

Lakoff G., Johnson M., Metafory w naszym życiu, przekład i wstęp T.P. Krzeszowski, Warszawa 1988

Małek B., Czy realizm magiczny? O prozie Andrzeja Stasiuka. „Annales Universitatis Paedagogicae Craciviensis. Studia HistoricoLiteraria" 2002, 1

Misztelas M., Dukielskie światło wedtug Stasiuka, 2014, <https://magdalenamisztelas.blogspot.com/ 2014/02/dukielskie-swiatlo-wedlug-stasiuka.html>, dostęp 1.07.2019

Nycz R., Literatura jako trop rzeczywistości, Kraków 2001

Nycz R., Poetyka doświadczenia. Teoria-nowoczesność-literatura, Warszawa 2012

Ricoeur P., Proces metaforyczny jako poznanie, wyobrażenie i odczuwanie, przekład G. Cendrowska, „Pamiętnik Literacki” 1984, z. 2

Stownik poprawnej polszczyzny PWN, pod red. A. Markowskiego, Warszawa 1999

Solan K., Proza Andrzeja Stasiuka jako „podręcznik meskości” - rzecz o tożsamości męskiej, „Barbarzyńca” 2009, 2(15)

Tokarczuk O., Ksieggi Jakubowe, Kraków 2014

Witosz B., Obrona bliskości w prozie Stasiuka, „Teksty Drugie" 2002, nr 5 